\title{
FROM ABSENCE TO (RE-)PRESENTATION: A READING OF THE FEMALE SUBALTERN'S BODY IN COETZEE'S WAITING FOR THE BARBARIANS
}

\author{
Duong Le Duc Minh* \\ VNU University of Languages and International Studies, \\ Pham Van Dong, Cau Giay, Hanoi, Vietnam
}

Received 3 September 2019

Revised 4 January 2020; Accepted 14 February 2020

\begin{abstract}
This research paper explores an alternative mode of knowledge-production for the representation of the barbarian girl in Coetzee's Waiting for the Barbarians. In light of Chandra Mohanty's critique pertaining the prominent academic methodologies that subsume all Third World women as homogenous and ahistorical subject of academic investigation, the paper offers an epistemological production of the barbarian girl's representation without committing the act of 'epistemic violence': perceived from the realm of the metatextual instead from that of the textual, the girl's somatic representation via its 'presence by absence' is recalcitrant and unyielding against the violence of imperialism.
\end{abstract}

Keywords: imperialism, metatextual, representation, feminist criticism

\section{Theoretical background and research rationale}

\subsection{Theoretical background: a feminist critique of a feminist methodology}

From the foundational ideas of Said's Orientalism to theoretical critiques deriving from the works of Meyda Yegenoglu's and Robert Young's, the issue of (re-) presenting the "Other" and the female subaltern in any academic discourse has been a constant intellectual struggle within the field of postcolonial theory. In 1984, Chandra Mohanty wrote "Under the Western Eye" critiquing prominent methodological approaches to feminist literary inquiry and discourse analysis concerning Third World women as subject of academic investigation. These methods of inquiry, as she elaborates, presuppose a position whereby they are seen solely as "sexual political subjects" that fall under the same group "Third World" and share the same "Third World Difference" (Mohanty, 1984, p.335). Those women are epistemically constructed and 'imagined' to be "stable" and "ahistorical" subjects; their oppressions are characterized simplistically by a seemingly universal notion of patriarchal hegemony in feminist discourse. Prescribing these subjects into a homogenous "coherent group in all contexts, regardless of class or ethnicity" (Mohanty, 1984, p. 335), emphasis in the original), this monolithic construction implicates a lack of profound relational reciprocity between "their materiality [in history] and their representation [in feminist discourse and scholarship]" (Mohanty, 1984, p. 335) in feminist writings. Having acknowledged this pitfall in feminist criticism, a fruitful investigation into the representation of the barbarian girl in Waiting for the Barbarians by J.M. Coetzee demands a scrupulous reading of her historical materiality in relation to her literary portrayal. However, while Stephen Watson's 
essay already addresses how the ambiguous depiction of the "Other" subjects — which comprises of the barbarian girl — rejects any foreclosed reading of their material substance, their abject status still alludes to an apparent hegemonic structure of imperialism. In other words, past works seem to take for granted this pertinent sense of absence in the Other's historical materiality operating within the narrative of the novel that could potentially complicate any process of articulating power dynamics between institution of imperialism and the "Other(ed)" subjects - especially at the level of the body, once the "Other" body is juxtaposed to that of the imperialist.

In addition, Spivak's "Can the Subaltern speak?" emphasizes the double-subjugation of the "Other" women in a colonial context since their subaltern state is characterized by a displacement of their agency which renders them voiceless within a doublebind hegemonic structure of colonialism and patriarchy - as iterated in Spivak's words, since "the ideological construction of gender keeps the male dominant" (Spivak, 2010, p. 83), and "if, in the context of colonial production, the subaltern has no history and cannot speak, the subaltern as female is even more deeply in shadow" (Spivak, 2010, p. 84). In that sense, if this analysis on the barbarian girl is based on a representation provided by a male imperialist - the Magistrate, will it just further reinforce her subaltern position? As a work aiming at contributing to a larger feminist scholarship, adopting such a method of inquiry will certainly classify this intellectual endeavor as an act of "epistemic violence"

Spivak implicitly remarks that this discourse of academic representation is often aligned with the imperialist narrative, which generates a sense of linear historical and social consciousness about the native and for the natives, so that they themselves will adopt their new identity as colonial subjects and succumb to Western domination. Nonwestern epistemology is thus disqualified as "naïve knowledge" and gradually becomes "subjugated" or marginalized knowledge (Spivak, 2010, p. 76). Therefore, it is crucial for this paper to disregard the Magistrate's representation of the barbarian girl and embrace the alternative method of reading into the presence through her absence in the narrative-in that sense, this paper does not provide yet another representation of the unnamed girl, but rather accentuates an alternative system of knowledge-making that is both cautious of its own pitfalls - that any literary, historical, or feminist material, untreated as such, must also be recognized as "an inaccessible blankness circumscribed by an interpretable text" (Spivak, 2010, p. 76) - and reactive to the imperialist mode of knowledge-making.

\subsection{Research rationale: an exegesis of the 'absence'}

This paper will not attempt to impose on the barbarian girl a (re-)presentation that threatens to overshadow her historical materiality; such an act conforms to the precarious methodology of literary inquiry that treats women as 'imagined' subjects for the sole purpose of academic investigation. Instead, it engages with the very absence of the barbarian girl representation as her own substance of textual materiality - in other words, the barbarian girl's representation within the narrative will be perceived to be 'present by absence'. Mobilizing this politics of absence is necessary for nuanced enunciations of power operating on and through the body of the barbarian girl during the process of colonial violence.

Even though this notion of absence hinges on the lack of representation of the barbarian girl throughout the narrative, it does acknowledge the representation of the barbarian girl within the narrative. However, the representation as such is focalized through the Magistrate - a sole narrator of the story who occupies an ambivalent position within the narrative. The word 
"ambivalent" distinguishes the Magistrate's conflicting complicity in the colonial violence of the Empire from Colonel Joll's apparent contribution to the consolidation of power and the performative practice of imperialism. The Magistrate manifests an identity of both a man working for the Empire, and yet that of "the [only] One Just Man" in the narrative (Coetzee, 1999, p. 152); this sense of ambivalence in determining the Magistrate's identity has been critically addressed in the work of Maria Boletsi. The problem at hand is that despite 'the benefit of the doubt' given to the complicity of the Magistrate to the Empire imperialist inclination, his perception, or representation, of the barbarian girl should not be perceived with credibility, to the extent that it cannot be employed for any works of literary inquiry since such an act will only perpetuate her already abject position as a female subaltern within the novel.

\section{Why can't the subaltern (woman) speak?}

An engagement with Brian May's essay "J.MCoetzee and the question of the body" will further illuminate the importance of perceiving the girl's representation as conspicuous by its absence since it allows the girl's historical materiality to maintain its existence at a level beyond textual transparency. May's essay provides many insightful and critical interpretations concerning the resistance and obstinacy of barbarian girl's body towards the colonial desire of the Empire; however, the argumentative foundation of the essay needs to be re-examined. While I agree that at purely textual level, "her history is a thing about which Coetzee's "barbarian girl" does not talk" (May, 2001, p. 391), and "her body, too, tells nothing" (May, 2001, p. 391), it is rather inadequate to state that the girl's body fails to signify both personal and imperial history (May, 2001, p. 392). Before May reaches this conclusion, she locates a significant amount of textual evidence that support this claim of such a failure, but all this evidence derives solely from the perspectives of the Magistrate himself. In other words, May imposes the
Magistrate's representation of the girl on that of herself, which further distances her own essay from obtaining a credible representation of the barbarian girl. Indeed, it is true that the whole novel's narrativization is focalized through the Magistrate's point of view, and that her history is neither signified by her body nor told by herself, the body should not be presumptuously denied of its material existence: the body's representational absence or excess defies conventional signification but does not suggest non-signification itself. In other words, even though as a reader, May are forced to perceive the story via the Magistrate's perspective and thus is denied access to the barbarian girl's history, the two points do not hold a logical causal relation that necessarily translate into the girl's nor her body's failure to tell a history. May's statement concerning the failure of the barbarian girl's body to signify a history is a concrete example of a critic's act of epistemic violence - a work of intellect produced purely on the privileged academic distance from the necessary tainted task of approaching the subaltern body with care and caution. Here, researchers need to distinguish as clearly as possible the preliminary stage of a violent deconstructive reading of the subaltern that necessarily re-inscribes the subaltern back to the state of radical alterity as such, from the more affirmative deconstructive reading of such a radical alterity into an experience of the (im)possible - the tainted task of the affirmative deconstructor, this research argues, following Spivak, cannot remain solely at the first stage. In May's article, the historical materiality of the barbarian girl is assumed to not have any presence, and as a consequence her unique depiction is as well undermined in the narrative - as May partially quotes the Magistrate at the end of her statement about the barbarian girl in Coetzee's novel:

Yet, to all appearances, Coetzee's barbarian girl leaves Waiting for the Barbarian just as she enters it, devoid of discernible history, not just anonymous, but anonymously piecemeal, a mere list 
of body parts, attitudes, and gestures that might belong to any "stocky girl with a broad mouth and hair cut in a fringe across her forehead staring over [the Magistrate's] shoulder" (May, 2001, p. 391-392)

May's concession to the Magistrate's representation of the barbarian girl affirms what Spivak highlights in any acts of epistemic violence - that such an act will signify a deeper level of subjugation of the subject "Other" and the perpetuation of their subaltern status. In a way, May's readily embrace of this metaphorical effacement of the barbarian girl's body renders such a subject truly anonymous and ahistorical, thus signifying the discourse - or the "heterogeneous project" — that only further subjugates the "Other(ed)" subject.

\section{An alternative mode of knowledge- production}

It is true that neither of the barbarian girl nor her body truly 'speaks' in the novel, but that should not propel scholars to impose their own representation, or a representation that they subjectively deem creditable, on the barbarian girl. If the narrative only allows a reading of the barbarian girl via absence, then it is within the 'presence by absence' that the representation of the girl remains the least treacherous. As Jenny Sharpe reads "Can the Subaltern Speak?" in her book Allegories of Empire, she articulates a very important point in Spivak's essay: "The story that cannot be told is the one of a subaltern woman who knows and speaks her exploitation. The story that must be told is the text of her exploitation" (Sharpe, 1993, p. 18). Indeed, since both the narrative structure and the Empire are complicit in silencing the barbarian girl from enunciating the exploitation of her body, that "text" seems to be inaccessible and absent from the narrative. However, her body still 'speaks' in its own language of resistance in silence, and this silence hence signifies its 'presence by absence'. Whether the girl is coerced into a voiceless position or she refuses to talk about her past, in either case, it does not necessarily mean her body is muted. While May's argumentative foundation claiming the failure of the girl's body to signify its history has been established as an act of epistemic violence, her analysis, which interprets the girl's body as a surface that "blocks or blanks all vision of its interior" but bears the ability to speak, still holds its validity (May, 2001, p. 413). This specific idea will be incorporated into that of mine to prove how the body claims its voice and asserts its representation via its 'presence by absence' at a metatextual level.

May argues that the Magistrate is incapable of perceiving what lies behind this surface because despite his relentless interpellations of her past (May, 2001, p. 413), all that can be achieved in the end is his feeling of rejection and alienation from that very body. While May employs the parting scene between the Magistrate and the barbarian girl to imply the insignificance and quotidian existence of the barbarian girl in the narrative - a reading in which I already criticize, I would interpret that same scene as a moment which not only punctuates the futility of all the Magistrate's attempts to understand the barbarian girl, but at the same time, allows the barbarian girl's body to 'voice' the traces of its somatic resistance without occupying any textual space in the narrative.

After the Magistrate embarks on a quest to bring the girl back to her people, there is a pertinent sense of intimacy developed between them; however, by the time he bids her farewell, he reaches an epiphany that his understanding of the girl remains as fragmented and unwholesome as when he first encounters her. As the Magistrate "[touches] her cheek [and] takes her hand" (Coetzee, 1999, p. 99), he finds no "trace in [himself] of that stupefied eroticism that used to draw [him] night after night to her body or even the comradely affection of the road" (Coetzee, 1999, p. 99). The outcome of all his effort to reach an understanding is a complete sense of "blankness" and "desolation" (Coetzee, 1999, 
p. 99). The fact that he himself acknowledges the inevitability of these feelings when he utters in his mind, "there has to be such blankness," (Coetzee, 1999, p. 99) signifies his acceptance of a defeat in this quest of unravelling her body's story. In their last moment together, he is confronted with the fact that he cannot historicize, or make into his story, her story of her body since he cannot penetrate further than the surface, he "caresses" to fulfill his many nights' desire (Coetzee, 1999, p. 40). After all these times, her interior remains intact, as she to him is similar to "a stranger" or "a visitor" from this foreign land, a person whose traits can only be captured not as a whole, but only in fragments of impression - "a stocky girl with a broad mouth and hair cut in a fringe across her forehead" (Coetzee, 1999, p. 99).

Since the whole scene is focalized through the Magistrate's narrative, the portrayed representation of the barbarian girl is, as argued, completely not credible. However, while concerning its textual surface, this passage does not indicate any representations of the barbarian girl since the focus is on the Magistrate's feeling of restlessness and defeat, the success of the girl's somatic resistance can somehow be summoned from the text. It is at this point of conflicting ideas that perceiving her representation as 'present by absence' from the narrative signifies its existence through alternative textuality. Within this level of metatextuality, her body is enabled to be expressive, which allows it to pronounce its successful resistance against the Magistrate's desire "to engrave himself on her as deeply as her torturer [does] and that of the Empire to "inscribe itself on the bodies of its subject" (May, 2001, p. 79) without occupying any textual substance. As May iterates this idea of an "expressive" body, she recognizes that "that the body does not speak to the Magistrate [from within the narrative] does not indicate that it cannot speak (May, 2001, p. 79), but she fails to find an explanation - that is, it speaks and demonstrates its resistance, in a language of silence and within its absence from the narrative. In brief, because the language of her body is absent from the textual substance of the narrative; it exists in an alternative textuality - and it is at this level of metatextuality that the body not only escapes the hegemonic oppression of the Magistrate's narrativization, but also his desire to penetrate it or to impose on it a representation produced by a colonial discourse. Her body existing within the narrative - or the Magistrate's perception - is a silent, not silenced, body; yet in alternative text, it arises as an obstinate and unyielding body. The body enunciates its resistance within the language of absence, thus allowing its owner, the barbarian girl, to reclaim the agency over that very body from the hegemonic power of the narrative and the systemic violence of imperialism.

\section{The visible body is an abject body; therefore, the visible body is NOT a muted body}

This idea of the body as a site of resistance is further complicated in light of Nirmal Puwar's theories concerning "invisible" and "visible" body when it is situated in a certain space. Puwar's dialectical dichotomy of "invisible" and "visible" body can also be re-interrogated through a reading of the girl's presence by absence. According to her theories, these notions of "invisible" or "visible" body should be conceptualized from a dialectical approach which comprises the dimension of "race, gender or any other social feature (Puwar, 2004, p. 57). In that case, considering the town of the settler as a platform for spatial analysis, the Magistrate is not marked by his own body because such a body does not deviate him from the norm, which is that of the "civilized people" (Coetzee, 1999, p. 33). This signifies his somatic embodiment as "invisible" and "unmarked" within that space. The barbarian girl, on the other hand, bears an "visible" and "marked" body since her body is characterized by the savagery recognized on that of the barbarian or even of "strange animals" (Coetzee, 1999, p. 26). Puwar hence argues that "the ideal representatives of humanity are those who are not marked by 
their own body and who are, in an embodied sense, invisible" (Puwar, 2004, p. 58). In relation to the novel, this idea of bearing "invisible" or "visible" body illuminates the reason why there is an unequal distribution of power invested in the Magistrate's body and that of the girl. Indeed, as the girl lies on his bed, the Magistrate realizes that he has power over this girl's body - a kind of power that would allow him to satisfy his desire for a sense of intimacy that can be equally achieved both by his idea of love and torture:

The girl lies in my bed, but there is no good reason why it should be a bed. I behave in some ways like a lover I undress her, I bathe her, I stroke her, I sleep beside her but I might equally well tie her to a chair and beat her, it would be no less intimate (Coetzee, 1999, p. 59-60)

This scene signifies the very nature of "a sexual contract" that propels colonizers to embark on their conquest to exotic land to fulfil their colonial desire as "knights in shining armor trampled here and there seeking out savagery and exotica while acquiring spices, gold, tea, sugar, cloth, jewels and land along the way" (Puwar, 2004, p. 23). More importantly, Puwar points out that "intrinsic to [this] project of despotic democracy has been the 'saving' of women from other places" (Puwar, 2004, p. 23), which is exemplified in the self-proclaimed 'rescue' of the barbarian girl from her wretched living condition by the Magistrate. Even though the girl would never have to suffer in the town of the settler if she hadn't been captured and tortured by Colonel Joll, the Magistrate still readily embraces this idea of "sexual contract" that legitimatizes his power over the girl's body as a vessel to satisfy his desire. Even he himself, by the end of the novel, acknowledges such a hypocrisy in this grotesque act of 'saving' or 'loving' the barbarian girl and her body: "For I was not, as I liked to think, the indulgent pleasure-loving opposite of the cold rigid Colonel. I was the lie that Empire tells itself when times are easy, he the truth that Empire tells when harsh winds blow. Two sides of imperial rule, no more, no less" (Coetzee, 1999, p. 180).

While Puwar's ideas concerning how power is vested on "invisible" and "visible" body is certainly not wrong, they render a rather reductive reading of how the Magistrate's "invisible" body is endowed with a sense of unchallenged power and authority from the hegemony of imperialism. Perceiving the body's "presence by absence", the novel also allows us to see this somatic power relation between that of the Magistrate and that of the barbarian girl's more nuancedly and a lot less one-sided. In one of the ablution scenes, in which the Magistrate called "the ritual of the washing", her body is disassembled into pre-processed fragments of materiality under the gaze fueled by the colonial desire. One by one - "her feet", "her legs", "her buttocks", "her thighs", "her armpits", "her belly", "her breasts", "her neck" and "her throat" (Coetzee, 1999 , p. 43) - is "touched" (Coetzee, 1999 , p. 44) and subjected under a sense of metaphorical violence. Indeed, in reference to Puwar's theories, her body becomes extremely "visible" and "marked" in the narrative space. However, from a state of absence, without occupying any textual substance of the narrative, her body enunciates its resistance in alter-text, disrupting this dialectic dichotomy of "visible" and "invisible" body by forcing the Magistrate to undergo the same process of disassembly, rendering the "invisible" body of the Magistrate "visible" within his own hegemonic narrativization:

"As for me, under her blind gaze, in the close warmth of the room, I can undress without embarrassment, baring my thin shanks, my slack genitals, my paunch, my flabby old man's breasts, the turkeyskin of my throat. I find myself moving about unthinkingly in this nakedness, ... (Coetzee, 1999, p. 43)".

Manifested in the relationship between the Magistrate and the barbarian girl, this political economy of power oscillating between the "visible" and the "invisible" body resonates 
with Judith Butler's ideas concerning the potentially subversive effect of juxtaposing "abject" body with "subject" body. The barbarian girl's body correlates with the idea of an "abjection" that signifies a "repudiation without which the subject cannot emerge" (Butler, 1993, p. 3) and affirms what Julia Kristeva claims, "[t]o each ego its object, to each superego its abject" (Kristeva, 1982, p.2). When the magistrate introspectively interrogates his feelings towards his mistress and the barbarian girl, he realizes that he never once has to question his own desire when he is with his mistress. As for the barbarian girl, "there is no link [he] can define between her womanhood and [his] desire" (Coetzee, 1999, p. 59) — or as conceptualized in Butler's theories - his desire cannot reside in her womanhood as it is an "unlivable and uninhabitable [zone]" which not only "is required to circumscribe the domain of the subject", but more importantly defines the limit of such a domain (Butler, 1993, p. 3). From the realm of alter-textuality, the girl's body serves as a "disavowed abjection" to the Magistrate's "subject" body, which "[threatens] to expose the self-grounding presumptions of [the sexed subject's desire]" (Butler, 1993, p. 3). In other words, as an abject body defining the limit of the Magistrate's subject body, the 'presence by absence' of the girl's body exists within the narrative as, in the words of Butler, "a threatening spectre" (Butler, 1993, p. 3), lurking in the novel's alter-text, awaiting not only to challenge the Magistrate's desire, but also to disavow the hegemonic power vested on his body by the act of narrativization perpetuated under the gaze of imperialism. Therefore, the girl's body, whose existence is characterized by its 'presence by absence', emerges as an abjection allowing a re-articulation of "the very terms of symbolic legitimacy and intelligibility" of the Magistrate's subject body (Butler, 1993, p. 3) - a seemingly "invisible" body in the space of the settler's town and his own narrative.

\section{Conclusion}

Aiming at offering a new mode of reading and knowledge-making when engaging with representation of investigated subject, the paper argues at length against precarious and specious attempts of imposing understanding upon such a subject at the expense of its historical materiality; this act of "epistemic violence", as a consequence, will only further subjugate the already muted subject. Inspired by Chandra Mohanty's essay "Under the Western Eye" and Spivak's influential work "Can the Subaltern Speak", this paper achieves an alternative conceptualization of the representation of the barbarian girl's 'presence by absence' in the hegemony of the Magistrate's imperialist narrativization. As a work of critical feminist criticism, it avoids committing the act of "epistemic violence" while articulating the nuances inherent in the encoding of colonial power on and through body. Within the theoretical framework constructed by the work of Nirmal Puwar and Judith Butler, these articulations are further complicated as they illuminate the subversive potential of the girl body's "presence by absence' - an "abjection" and a "spectre" that subverts the power economy structured on the dialectical dichotomy of "visible" and "invisible" body and consequently renders the Magistrate's "subject" body highly visible in his own hegemonic narrativization.

\section{References}

Boletsi, M. (2007) Barbarian Encounters: Rethinking Barbarism in C.P. Cavafy's and J.M Coetzee's Waiting for the Barbarians. Comparative Literature Studies, 44 (1-2), 67-96.

Butler, J (1993). Bodies that Matter: On the Discursive Limits of "Sex". NY: Routledge.

Coetzee, J.M (1999). Waiting for the Barbarians. NY: The Penguin Group.

Kristeva, J. (1982). Approaching Abjection. Powers of Horror: An Essay on Abjection. Trans. Leon S. Roudiez. NY: Columbia UP.

May, B. (2001). J.M Coetzee and the Question of the Body. Modern Fiction Studies, 47(2), 391 - 420. 
Mohanty, C. (1984). Under the Western Eyes: Feminist Scholarship and Colonial Discourse. Boundary 2, 12(3), 333-358.

Puwar, N (2004). Space Invaders: Race, Gender and Bodies Out of Place. London: Bloomsbury Academic.

Sharpe, J (1993). Allegories of Empire: The Figure of Women in the colonial text. Minnesota: University of Minnesota Press.

Spivak, G. C. (2010). Can the subaltern speak? Reflections on the History of an Idea (pp. 21-78). NY: Columbia University Press.

---. (1999). A Critique of Postcolonial Reason: Toward a History of the Vanishing Present. Cambridge: Harvard UP.

---. (2006) In Other Worlds. New York/ London: Routledge.

---. (2009) Outside in the Teaching Machine. New York/ London: Routledge.

Watson, S. (1996). Colonialism and the Novels of J.M Coetzee. Research in African Literatures, 17 (3), 370-392.

Young, R. (2005). Colonial Desire: Hybridity in Theory, Culture and Race. NY: Routledge.

Yegenoglu, M. (1999) Colonial Fantasies: Towards a Feminist Reading of Orientalism. Cambridge: Cambridge University Press.

\title{
TÙ SỰ VÔ DIỆN ĐẾN SỰ (TÁI) TRÌNH DIỆN: MỘT PHÂN TÍCH VỀ NGƯỜI NŨ̉ NHƯợC TIỂU TRONG TÁC PHẨM Đợi BỌN MỌI CỦA COETZEE
}

\author{
Dương Lê Đức Minh \\ Truờng Đại học Ngoại ngũ , Đại học Quốc gia Hà Nội \\ Phạm Văn Đồng, Cầu Giấy, Hà Nội, Việt Nam
}

Tóm tắt: Nghiên cứu này tìm hiểu một phương thức luận tri thức khác cho sự trình hiện của cô gái man rợ trong tác phẩm Đợi Bọn Mọi của Coetzee. Dựa trên những phê bình của Chandra Mohanty về cách thức luận học thuật phổ biển, cách thức nhìn nhận phụ nữ thế giới thứ ba như một chủ thể đồng nhất và phi lịch sử, nghiên cứu đưa ra một thức luận khác về trình hiện cô gái man rợ mà tránh được hành vi 'bạo lực tri thức': Từ thế giới siêu văn bản thay vì văn bản, trình hiện cơ thể của cô gái hiện diện qua sự thiếu vắng có thể hiểu như một phương thức kháng cự và sự không chịu khuất phục trước sự bạo hành của chủ nghĩa đế quốc.

Tù khóa: chủ nghĩa đế quốc, siêu văn bản, trình hiện, phê bình nữ quyền 